\title{
Milena Valenčič Zuljan and Jana Kalin, Instructional Methods and the Teacher's Methodical Competence (In Slovene: Učne metode in razvoj učiteljeve metodične kompetence), Pedagoška fakulteta UL: 2020; 232 pp.: ISBN: 9789612532628
}

Reviewed by Romina PlešEc Gasparič ${ }^{1}$

The monograph Učne metode in razvoj učiteljeve metodične kompetence (Instructional Methods and the Teacher's Methodical Competence, Valenčič Zuljan and Kalin, 2020) is 232 pages long and divided into nine chapters, a subject index and an author index. It consists of two parts. In the first part, the authors theoretically define instructional methods and focus on the methodical competence of the teacher, while the second part offers an insight into the practical experiences of thirteen teachers: their planning, implementation and evaluation of instructional methods in everyday school life.

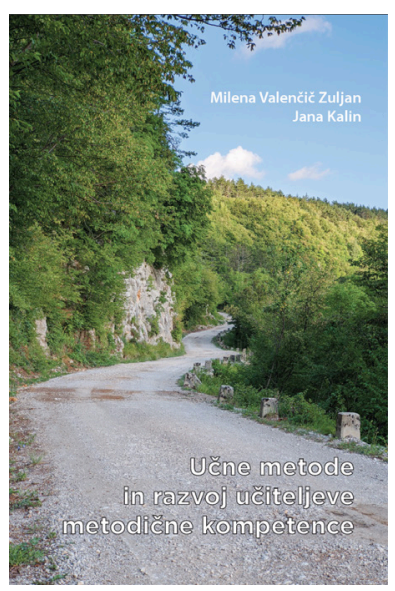

In the introduction, the authors explain the purpose of the monograph, which is to contribute to critical reflection on teachers' own planning, implementation and evaluation of instructional methods.

In the first chapter, the authors deal with the definition of the central concept. Their starting point is Poljak's (1974) statement that there is no other didactical field that has as many divergences as the field of instructional methods. Poljak (1974) demonstrates that the terminological and conceptual confusion in didactics arises because "the definition of instructional methods is often identified with many other issues of instruction, i.e., sources of knowledge, cognitive functions, sociological forms of grouping, different methodical concepts of instruction of a particular subject, etc." (p. 87). Similarly, Lavrnja (1996) problematises both the terminology and the definition of instructional methods.

Valenčič Zuljan and Kalin (2020) provide an overview of national and international classifications, which are synthesised in the second chapter, and

1 Faculty of Education, University of Ljubljana, Slovenia; Romina.Plesec@pef.uni-lj.si. 
agree with Poljak (1974) and Lavrnja (1996) regarding the aforementioned divergence. The authors present various classifications in their book, on the basis of which they develop their own classification, drawing from both traditional and contemporary teaching premises. Additional visual support is provided by a scheme that clearly presents their classification (Valenčič Zuljan and Kalin, 2020, Figure 1, p.16).

The text is underpinned with important domestic and foreign sources and research findings, from the "pioneers" of didactics (e.g., Komensky, Bloom; Slovenian author Šilih), to the most contemporary researchers of the field. The latest research connected with instructional methods and emphasising the factors of effective teaching give the text a special breadth; traditional didactic thinking is constantly met with modern concepts of teaching.

In the third, main chapter of the monograph, the authors introduce each instructional method, defining it in detail at the beginning of each subchapter. They present its use, advantages and limitations, connecting it to instructional objectives, instructional principles, instructional phases and the grouping of students, thus constantly drawing attention to the interconnectedness of factors and the complexity of instruction. Each individual method is discussed in its instructional context, providing an insight into its specificity, while also shedding light on the web that a particular instructional method weaves with other instructional methods and with other didactic elements of instruction.

Instructional methods are presented as a concept that is sharply delineated and does not allow for the addition of methods, but is nonetheless open to the possibilities of information and communication technologies, to the changing relationship between teachers and learners, and to contemporary notions of effective instruction.

In Chapter 4, the authors introduce instructional methods in the function of differentiation and individualisation as one of the ways to adapt instruction. They define the terms differentiation and individualisation in detail and explain their applicative value, emphasising that their application is a complex skill that requires the teacher to have a thorough understanding of the content and the characteristics of the students, as well as excellent teaching skills and a firm grasp of teaching approaches and strategies (p. 105).

Chapter 5 highlights the teacher's professional development in methodical competence, which is first defined and explained. The authors then systematically present the contextual knowledge necessary for the development of methodical competence.

In Chapter 6, Valenčič Zuljan and Kalin (2020) contrast the concepts of instructional method, instructional strategy and didactic strategy, and discuss 
their mutual connections. Terminologically and conceptually, it is very valuable to be introduced to some didactic strategies: traditional, inquiry, project-based, problem-based, programme-oriented, work-based and team-based instruction. The authors conclude the chapter with a review of research findings on these didactic strategies.

In the theoretical section, the text goes into depth, but also provides cognitive support through numerous concrete and practical examples of the application of each instructional method. These examples are from different subject areas, different subject content and different instructional situations, enabling the authors to address a wide range of readers.

In the monograph, the authors share their personal approach to each problem, encouraging critical reading and finding adequate solutions. Through their reflection, they always acknowledge the importance of the "old" school and traditional instruction, while also emphasising the possibilities of modern instruction. In doing so, they enhance the work of their predecessors and enrich it with new dimensions. In the notes, the more sophisticated reader can find additional detailed explanations of some terms, comparisons of the ideas of different authors, and references to additional reading and research reports.

The theoretical part of the monograph is enhanced by teachers' experiences, which occupy a special place in the monograph: the authors emphasise the autonomy of teachers when it comes to method modification, as each instance of instructional method implementation is creative and inimitable, and together with other didactic elements (student grouping, instructional phases, instructional objectives and instructional principles) forms a unique instructional situation.

The experiences shared by the teachers make visible the processes of planning, implementing and evaluating lessons, and allow the reader with previous pedagogical experience to identify with the teachers' experiences. Above all, such readers will identify with the professional development described by the teachers, reflect on their own teaching practice, perhaps come to terms with the difficulties they struggled with themselves as novices, and gain confirmation that the stages of professional development are similar for most teachers, regardless of the educational level at which they teach.

The authors summarise their theoretical reflections and research findings in the final chapter.

In their reflections, the authors point out dilemmas and pitfalls that are usually not fully accessible to us because of our habitual perspective and routine. They draw particular attention to a mono-method approach, on the one hand, and to method clustering, on the other, which can result from our desire 
for variety. The authors emphasise thoughtful selection and thorough preparation for every implementation of instruction. The common thread throughout the text is the authors' constant emphasis on the importance of method modification and the mutual combination of methods. Special importance is ascribed to constant professional reflection on one's own teaching and the development of methodical competence.

Focusing primarily on instructional methods, the monograph was necessary and expected, as it helps us understand the breadth, depth and importance of instructional methods. It is also a guidepost when deciding between different methods: the ways or paths that will lead us to the established instructional goals. One of the main merits of the book is that it appeals to a wide range of readers. In educational settings, it will be indispensable for school leaders who observe and care about the quality of instruction. It will also assist school counsellors when they need to find ways to help teachers and students with diverse learning needs. The book will be a fundamental resource for all university students of education in their early stages of acquiring methodical competence. The book is no doubt primarily intended for teachers at all levels of education - from preschool to university - as it provides support, presents practical experiences and, through personal narratives of teachers, gives all teachers autonomy in implementing instructional methods.

There are several reasons why translations of didactic terms are problematic, including different academic, scientific and research starting points (Protner \& Wakounig, 2007; Skubic Ermenc, 2014) and the accessibility of international scientific literature. Translation is particularly problematic in the area of instructional methods; in the Anglo-Saxon world, the common term "teaching methods" is quite loose, if not all-encompassing, and does not achieve the precision of the definition of instructional methods that we know (and aspire to). This is one of the reasons we decided to use the term "instructional" instead of "teaching" methods in this book review. Despite the fact that instructional methods are defined and delineated, they are still a dynamic concept that depends on many influencing factors, so they will certainly be a topic of ongoing discussion in the future. The book Instructional Methods and the Teacher's Methodical Competence (2020), written by renowned Slovenian didactics experts, Prof. Dr Milena Valenčič Zuljan and Prof. Dr Jana Kalin, is an important milestone in the development of contemporary didactics in Slovenia and elsewhere, enabling us to approach greater terminological and conceptual clarity in this field. Moreover, we are reminded that despite the innovation of instruction and the ever greater use of ICT, instructional methods remain one of the main factors influencing the quality of instruction. 


\section{References}

Lavrnja, I. (1996). Poglavlja iz didaktike [Chapters from didactics]. Pedagoški fakultet u Rijeci.

Poljak, V. (1974). Didaktika [Didactics]. Državna založba Slovenije.

Protner, E., \& Wakounig, V. (2007). Podobe reformske pedagogike [Images of reform pedagogy].

Sodobna pedagogika, 4(58), 6-22.

Skubic Ermenc, K. (2014). Prevajanje pojma "pedagogika” v angleški jezik in primer primerjalne pedagogike [Translation of the term "pedagogy" into English and the case of comparative pedagogy].

Sodobna pedagogika 1(65), 56-71.

Valenčič Zuljan, M., \& Kalin, J. (2020). Učne metode in razvoj učiteljeve metodične competence

[Teaching methods and development of teachers' methodical competence]. Univerza v Ljubljani,

Pedagoška fakulteta. 